\title{
A short note on HBV infection
}

\section{Aiswarya Muraleedharan \& Giridharan Bupesh*}

${ }^{1}$ Research and Development Wing, Central Research Laboratory, Sree Balaji Medical College and Hospital (SBMCH), BIHER, Chrompet, Chennai - 600044, India; *Corresponding Authors: Dr. Giridharan Bupesh, Associate Director, R\&D Wing, Sree Balaji Medical College and Hospital, BIHER, Chromepet, TamilNadu-600044, Phone: +91 8012405965, Email: bupeshgiri55@gmail.com; *Corresponding author

Received January 1, 2020; revised May 25, 2020, Accepted May 30, 2020; Published July 31, 2020

DOI: $10.6026 / 97320630016501$

Declaration on official E-mail:

The corresponding author declares that official e-mail from their institution is not available for all authors

\section{Declaration on Publication Ethics:}

The authors state that they adhere with COPE guidelines on publishing ethics as described elsewhere at https://publicationethics.org/. The authors also undertake that they are not associated with any other third party (governmental or non-governmental agencies) linking with any form of unethical issues connecting to this publication. The authors also declare that they are not withholding any information that is misleading to the publisher in regard to this article.

\section{Abstract:}

HBV-related liver sickness or hepatocellular carcinoma is common worldwide. Therefore, it is of interest to document the current trends in hepatitis prevention, diagnosis, treatment and care.

Keywords: $\mathrm{HBV}$, infection, update, diagnosis, treatment, prevention

\section{Description}

Hepatitis B infection (HBV) is a global health issue. [1,2]. The presentation models for hepatitis $B$ through immunizations is critical [3]. Hepatitis B surface antigen (HBsAg) is found on the surface of the infection by self-assembling, non-infectious circular or tubular particles [4]. The genome ORF encodes those three viral envelope proteins: large (L-), medium (M-), Also small (S-) surface antigen (HBsAg). A substitute ORF encodes precore, suggested as HBV e antigen (HBeAg), and the inside protein as the viral capsid. The ORF encodes the HBV $X$ protein $(\mathrm{HBx})$ [4]. The transcription factor-intervened guideline of $\mathrm{HBV}$ transcription has been described [5]. The HBeAg ORF encodes an endoplasmic reticulum (ER) [6]. HBeAg is fundamental for HBV replication [7]. The envelope proteins are incorporated in ER to form the transmembrane arrangement [8]. The luminal circle holds the major conformational epitope for HBsAg that is glycosylated on the Sprotein moieties [9]. The adaptation of $\mathrm{L}$ is fundamental for capsids to assemble HBV virions [10]. These proteins make up the viral envelope [11]. SVPs are created with S-HBsAg, containing MHBsAg and L-HBsAg [12]. The center protein in the HBV life cycle is a component of the capsid [13, 14]. The inverse association between age and risk of chronic infection is responsible for the burden of morbidity and mortality to HBV [15]. At 6-12 months after infection, the immunoglobulin $M$ antibodies to hepatitis $B$ center antigen are imperceptible [16, 17]. Immuno-suppressed persons might create reactivation from claiming $\mathrm{HBV}$ contamination resulting in hepatocellular carcinoma [18]. $\mathrm{HBeAg}$, a marker for secondary viral action correlates with infectivity [19]. Low rate for HBsAg with medication in numerous patients is known $[20,21]$. Transmission from a chronically infected woman 


\section{BIOINFORMATION \\ Discovery at the interface of physical and biological sciences}

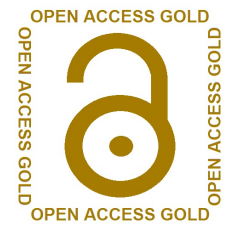

with her newborn child throughout conveyance is productive [22]. Hepatitis B antibodies in immunization formulations utilizing twofour dose schedules are allowed in the United States [23]. Hepatitis $\mathrm{B}$ antibodies are immunogenic and post inoculation serologic demanding in the United States is observed under uncommon circumstances [24]. The structure of HBV surface antigen with correlation of subtype with amino acid sequence and location of the carbohydrate moiety is available [25]. Suspicions on viral safety in vaccine development are a concern [26]. Natural History and Clinical Consequences of Hepatitis B Virus Infection is a fear. [27]. The antivirals treatment in pregnant women is contraindicated in this case [28-30]. Rapid and sensitive assays for the determination of HBV genotypes and detection of HBV precore and core promoter variants are now available [14]. Thus, we document the current trends in hepatitis prevention, diagnosis, treatment and care in this short note.

\section{References:}

[1] Revill PA et al. Lancet Gastroenterol Hepatol 2019 4:545 [PMID: 30981686].

[2] Polaris Observatory Collaborators. Lancet Gastroenterol Hepatol 2018 6:383 [PMID: 29599078].

[3] Indolfi G et al. Lancet Gastroenterol Hepatol 2019 4:466 [PMID: 30982722].

[4] Seto WK et al. Lancet 2018 392:2313 [PMID: 30496122].

[5] Yuen MF et al. Nat Rev Dis Primers 2018 4:18035 [PMID: 29877316]

[6] Fanning GC, et al Nat Rev Drug Discov 2019 18:827. [PMID: 31455905].

[7] Raimondo G, et al J Hepatol 2019 71:397. [PMID: 31004683].

[8] Ganem D, et al. N Engl J Med 2004 350:1118 [PMID: 15014185]
[9] Wu CC, et al. World I Gastroenterol 2018 24:3488 [PMID: 30131655].

[10] Nelson NP et al. Clin Liver Dis 2016 20:607 [PMID: 27742003].

[11] $\mathrm{Hu}$ J et al. Gastroenterology 2019 156:338 [PMID: 30243619].

[12] Boeijen LL et al. Best Pract Res Clin Gastroenterol 2017 31:265 [PMID: 28774408].

[13] Nainan OV et al. J Med Virol 2002 68:319 [PMID: 12226817].

[14] Hussain M et al. J Clin Microbiol 2003 41:3699 [PMID: 12904378].

[15] Takkenberg RB et al. Vox Sang 2010 98:481 [PMID: 19951307].

[16] McMahon BJ, Clin Liver Dis 2010 14:381 [PMID: 20638020].

[17] Liaw YF \& Chu CM, Lancet 2009 373:582 [PMID: 19217993].

[18] Keasler VV et al. J Virol 2007 81:2656 [PMID: 17182675].

[19] Nassal M, Gut 2015 64:1972 [PMID: 26048673].

[20] Seeger C \& Mason WS, Virology 2015 479-480C: 672 [PMID: 25759099].

[21] Doitsh G \& Shaul Y, Mol Cell Biol 2004 24:1799 [PMID: 14749394].

[22] Chen MT et al. Proc Natl Acad Sci USA 2004 101:14913 [PMID: 15469922].

[23] Chen M et al. J Virol 2005 79:3016 [PMID: 15709022].

[24] Liaw YF, Hepatol Int 2009 3:425 [PMID: 19669245].

[25] Peterson DL et al. J Biol Chem 1982 257:10414 [PMID: 7107612].

[26] Urban S et al. Gastroenterology 2014 147:48 [PMID: 24768844].

[27] Ganem D \& Prince AM, N Engl J Med 2004 350:1118 [PMID: 15014185].

[28] Bruns M, J Virol 1998 72:1462 [PMID: 9445049].

[29] Melegari M et al. J Virol 2005 79:9810 [PMID: 16014942].

[30] Bock CT et al. J Mol Biol 2001 307:183 [PMID: 11243813].

Edited by P Kangueane

Citation: Muraleedharan \& Bupesh, Bioinformation 16(7): 505-508 (2020)

License statement: This is an Open Access article which permits unrestricted use, distribution, and reproduction in any medium, provided the original work is properly credited. This is distributed under the terms of the Creative Commons Attribution License 


\section{BIOINFORMATION}

Discovery at the interface of physical and biological sciences

Articles published in BIOINFORMATION are open for relevant post publication comments and criticisms, which will be published immediately linking to the original article for FREE of cost without open access charges. Comments should be concise, coherent and critical in less than 1000 words. 


\section{BIOINFORMATION}

Discovery at the interface of physical and biological sciences


since 2005

\section{BIOINFORMATION}

Discovery at the interf ace of physical and biological sciencess

\section{indexed in}

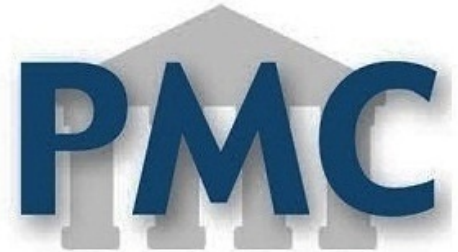

PublMed



EBSCO

ResearchGate
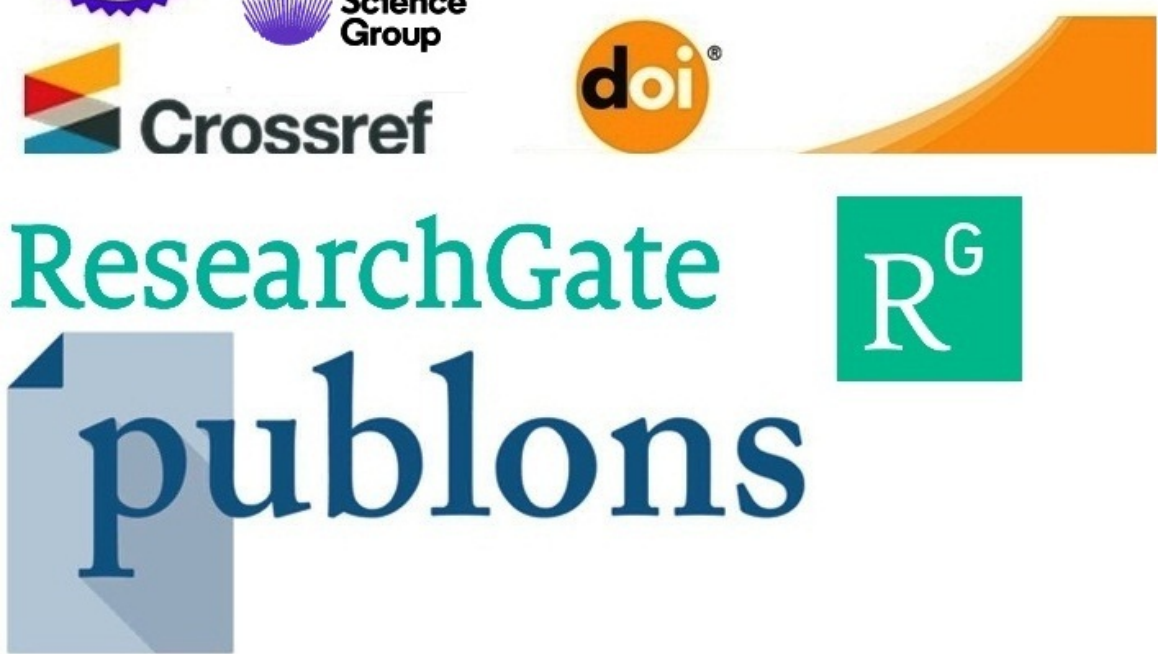